\title{
IZVJEŠĆE NEOVISNOG REVIZORA KAO INSTRUMENT ZA POBOLJŠANJE TRANSPARENTNOSTI FINANCIJSKOG IZVJEŠTAVANJA I KVALITETE REVIZIJE
}

\author{
INDEPENDENT AUDITOR'S REPORT AS AN INSTRUMENT \\ TO IMPROVE THE TRANSPARENCY OF FINANCIAL \\ REPORTING AND AUDIT QUALITY
}

SAŽETAK: Financijski izvještaji predstavljaju jedan od osnovnih instrumenata kojima se donose poslovne odluke. Da bi oni kao takvi predstavljali temelj za donošenje poslovnih odluka, potrebno je dokazati njihovu realnost i objektivnost u iskazivanju financijskog položaja i uspješnosti poslovanja. Mišljenje o realnosti i objektivnosti financijskih izvještaja neovisni eksterni revizor iskazuje u izvješću neovisnog revizora. S obzirom na to da je izvješće namijenjeno eksternim korisnicima, standardizirano je, zbog čega su upućene brojne kritike revizijske profesije da takvo izvješće ne daje dovoljno informacija korisnicima. Zbog toga je došlo do promjene regulatornog okvira, u kojemu se dodaju novi elementi u izvješće neovisnog revizora. Između ostalog, revizor je dužan izvještavati o ključnim revizijskim pitanjima. Izvještavanje o ključnim revizijskim pitanjima trebalo bi doprinijeti manjoj informacijskoj asimetriji i povećati kvalitetu financijskog izvještavanja i revizije. Doprinos ključnih revizijskih pitanja kvaliteti revizije u izvješću još uvijek je neistraženo područje. U tom smislu rad predstavlja kritičku analizu postojećih istraživanja o doprinosu izvještavanja o ključnim revizijskim pitanjima kvaliteti revizije. Osim toga, rad daje pregled ključnih revizijskih pitanja o kojima izvještavaju revizori na primjeru izdavatelja na Zagrebačkoj burzi.

KLJUČNE RIJEČI: revizija financijskih izvještaja, izvješće neovisnog revizora, ključna revizijska pitanja, kvaliteta revizije

ABSTRACT: Financial statements are one of the basic instruments used to make business decisions. In order for them to represent the basis for making business decisions, it is necessary to prove their true and fairview of financial position and performance. The

Izv. prof. dr. sc. Sanja Sever Mališ, Ekonomski fakultet - Zagreb, ssever@net.efzg.hr 
opinion on the true and fairview of the financial statements is expressed by the independent external auditor in the independent auditor's report. Since the report is intended for external users, it has been standardized, which is why many criticisms of the audit profession have been made that such a report does not provide enough information to users. As a result, there has been a change in the regulatory framework in which new elements are added to the independent auditor's report. Among other things, the auditor is required to report on key audit matters (KAM). Reporting on key audit matters should contribute to less information asymmetry and increase the quality of financial reporting and auditing. The contribution of key audit issues to audit quality in the report is still an unexplored area. In this regard, the paper presents a critical analysis of existing research on the contribution of reporting on key audit matters to audit quality. In addition, the paper provides an overview of key audit issues that auditors report on the example of issuers on the Zagreb Stock Exchange.

KEY WORDS: financial statements audit, independent auditor's report, key audit matters, quality of audit

\section{UVOD}

Financijski izvještaji predstavljaju jednu od temeljnih informacijskih podloga za donošenje poslovnih odluka. Međutim, da bi oni poslužili toj svrsi potrebno je osigurati njihovu realnost i objektivnost. Osim toga, tržišta kapitala zahtijevaju visokokvalitetne informacije te potvrdu financijskih informacija koje je pripremio i za koje je odgovoran menadžment. U tom smislu neovisna eksterna revizija financijskih izvještaja u sustavu korporativnog upravljanja treba potvrditi visoku kvalitetu financijskih informacija. Proces dokazivanja da su financijski izvještaji realni i objektivni je kompleksan proces determiniran metodologijom obavljanja revizije i određen u Međunarodnim revizijskim standardima. Međutim, konačan produkt revizije financijskih izvještaja je izvješće neovisnog revizora koje je kao takvo standardizirano strukturom i sadržajem. Drugim riječima, kompleksan revizorov rad rezultira izvješćem u kojem se izražava mišljenje koje je kao takvo standardizirano. U tom smislu brojne kritike upućene su regulatorima i donositeljima standarda o tome kako treba unaprijediti izvješće neovisnog revizora na način da stvori dodanu vrijednost korisnicima u odnosu na ono što je predstavljeno u financijskim izvještajima. Regulatori širom svijeta, uključujući i Odbor za javni nadzor nad računovodstvom javnih poduzeća (engl. Public Company Accounting Oversight Board - PCAOB) i Međunarodni odbor za standarde revidiranja i izražavanja uvjerenja (engl. International Auditing and Assurance Standards Board - IAASB), odgovorili su na brojne kritike koju su upućivali računovodstveni i revizijski stručnjaci o netransparentnosti revizorovih izvješća. U konačnici, to je rezultiralo uvođenjem dodatnih elemenata u izvješće neovisnog revizora, od kojih se posebno izdvaja obveza izvještavanja o ključnim revizijskim pitanjima koja je revizor uočio u postupku obavljanja revizije financijskih izvještaja. Regulatori su pretpostavili da bi ključna revizijska pitanja trebala biti povezana s manjom informacijskom asimetrijom i jazom očekivanja te samim time povećati kvalitetu financijskog izvještavanja i kvalitetu revizije. 


\section{IZVJEŠĆE NEOVISNOG REVIZORA KAO INSTRUMENT TRANSPARENTNOSTI FINANCIJSKOG IZVJEŠTAVANJA S NAGLASKOM NA KLJUČNA REVIZIJSKA PITANJA}

Izvješće neovisnog revizora predstavlja formalnu komunikaciju revizora s korisnicima financijskih izvještaja i zaključak revidiranih financijskih izvještaja. Sukladno revizijskim standardima, forma i sadržaj revizorova izvješća propisani su, što čini takav izvještaj relativno standardiziranim. U tom smislu izvješće neovisnog revizora predstavlja instrument komunikacije korisnicima financijskih izvještaja. Kako bi ta komunikacija bila efikasna, standardizacija se odnosi na objašnjene odgovornosti menadžmenta i odgovornosti revizora u revizijskom procesu s mišljenjem o tome prikazuju li financijski izvještaji realno i fer financijski položaj i uspješnost poslovanja klijenta. Usprkos detaljnom objašnjenju sadržanom u revizorovu izvještaju o tome što su odgovornosti menadžmenta, a što su odgovornosti revizora, u razumijevanju uloge i značenja revizije u procesu financijskog izvještavanja između korisnika i revizora javlja se tzv. jaz očekivanja. Jaz očekivanja javlja se jer korisnici financijskih izvještaja precjenjuju revizorove obveze i odgovornosti (Brozović, 2018). Jedan od značajnih prigovora koji proizlazi iz jaza očekivanja jest neefikasnost revizora u otkrivanju prijevare u financijskim izvještajima. Naime, brojna su istraživanja pokazala da zakonska revizija nije efikasna u otkrivanju prijevare, a revizorova izvješća ne daju niti jednu informaciju o tome sadrže li financijski izvještaji rizike materijalno pogrešnog prikazivanja nastalog kao posljedica prijevare. To dovodi u pitanje komunikacijsku i informativnu vrijednost revizorova izvješća.

Ključni odlomak revizorova izvješća je odlomak u kojem se izražava mišljenje. Pri tome standardno pozitivno mišljenje znači da financijski izvještaji u svim materijalno značajnim odrednicama odražavaju istinito i fer financijski položaj i uspješnost poslovanja klijenta. Nasuprot tome, mišljenje može biti negativno, što znači da financijski izvještaji nisu prikazani istinito i fer u skladu s primjenjivim okvirom financijskog izvještavanja. Osim toga, revizor može izraziti mišljenje s rezervom, kojim upućuje u kojim segmentima financijski izvještaji odstupaju od primjenjivog okvira financijskog izvještavanja. Lenox je 2005. godine na uzorku od 28.292 mišljenja koja su izdali revizori u razdoblju od 1995. do 1998. godine pokazao kako je 99,8 \% svih mišljenja nemodificirano (pozitivno), 0,1 \% mišljenja je s rezervom, a $0,1 \%$ negativnih mišljenja. S obzirom na to da su sva revizorova mišljenja pisana standardiziranim jezikom, dionici i regulatori izrazili su zabrinutost kako je tradicionalni model izvještavanja revizora zapravo neinformativan (Lennox, 2005; Lennox et al. 2021). Pokazano je da čak i mali postotak mišljenja koja su različita od pozitivnog ne izaziva značajne reakcije na tržištu kapitala.

$\mathrm{U}$ tom smislu, zadnjih godina mnogo je pregovora i inicijativa usmjereno $\mathrm{k}$ tome kako poboljšati kvalitetu revizorova izvještavanja. Ugledno revizijsko društvo nazvalo je to tragedijom za revizore na način da je na desetke tisuća sati revizijskog posla reducirano na jedan standardni obrazac teksta, čime se izvješće neovisnog revizora velike banke jedva razlikuje od regionalnog društva koje se bavi proizvodnjom. Usprkos marljivom poslu revizora, velika većina ostvarenih napora ostane skrivena od dioničara (PwC, 2014, str. 4). Ustvari, revizor revidira mnoge pretpostavke vrijednosti, kompleksna porezna pitanja, rezerviranja, priznavanja prihoda te realnost sustava i procesa, a sve to skupa ostaje skriveno od široke javnosti. 
U tom smislu, investitori su tražili od revizora da objave više informacija o područjima visokog rizika financijskog izvještavanja i revizijskog rizika. Još je 2011. godine Odbor za međunarodne standarde revidiranja i izražavanja uvjerenja (engl. International Auditing and Assurance Standards bord - IAASB) iznio brojne prijedloge kako poboljšati revizorovo izvještavanje. Predložene promjene odnosile su se na: format i strukturu revizorova izvješća, ostale informacije u dokumentima koje sadržavaju revidirane financijske izvještaje, revizorovo usmjeravanje korisnika na značajna pitanja o reviziji i revidiranim financijskim izvještajima, poboljšan model izvještavanja u sustavu korporativnog upravljanja te ostala uvjerenja i povezane usluge o informacijama koja nisu trenutno u djelokrugu revizije financijskih izvještaja (IAASB, 2011; Sever Mališ, Tušek, Žager, 2012). Između navedenog, značajna pažnja u tom dokumentu usmjerila se na ključna pitanja o reviziji i revidiranim financijskim izvještajima (IAASB, 2011)

U konačnici, 2015. godine ključna revizijska pitanja implementirana su u Međunarodni revizijski standard (701) pod nazivom Priopćavanje ključnih revizijskih pitanja u izvješću neovisnog revizora. U tom smislu ključna revizijska pitanja definirana su kao ona pitanja koja su, po revizorovoj profesionalnoj prosudbi, od najveće važnosti u reviziji financijskih izvještaja tekućeg razdoblja (MRevS 701, para. 8). Ključna revizijska pitanja odabiru se između pitanja o kojima se komuniciralo s onima koji su zaduženi za upravljanje. Pri određivanju ključnih revizijskih pitanja revizor će uzeti u obzir: a) područja s višim procijenjenim rizikom značajnog pogrešnog prikazivanja ili sa značajnim rizicima; b) važne revizorove prosudbe u vezi s područjima u financijskim izvještajima koja sadrže važne menadžmentove prosudbe, uključujući računovodstvene procjene koje su bile prepoznate kao one s visokim stupnjem nesigurnosti procjene, te c) učinak na reviziju uslijed važnih događaja ili transakcija nastalih tijekom razdoblja (MRevS 701, para. 9). Primjena ovog standarda percipirana je kao poboljšanje komunikacijske ili informativne vrijednosti izvješća neovisnog revizora.

U tom smislu ključna revizijska pitanja potrebno je objaviti u revizorovu izvješću koristeći odgovarajući podnaslov „ključna revizijska pitanja“. U uvodnom tekstu ovog odjeljka revizorova izvješća navest će se: a) ključna revizijska pitanja jesu ona pitanja koja su, po revizorovoj profesionalnoj prosudbi, od najveće važnosti u reviziji financijskih izvještaja [tekućeg razdoblja]; i b) ta se pitanja navode u kontekstu revizije financijskih izvještaja kao cjeline i formiranja revizorova mišljenja o njima, te da revizor ne daje odvojeno mišljenje o tim pitanjima (Mrevs 701, para. 11). Pritom je važno naglasiti kako ključna revizijska pitanja nisu zamjena za izražavanje modificiranog mišljenja. Osim toga, revizor je dužan objasniti ključno revizijsko pitanje i to na način da objasni: a) zašto se smatra da je pitanje jedno od najveće važnosti u reviziji i stoga je određeno da je ključno revizijsko pitanje; b) kako se u reviziji bavilo s tim pitanjem (MRevS 701, para. 13). Osobito je važno istaknuti u kojem su odnosu ključna revizijska pitanja s pitanjima koja uzrokuju izražavanje modificiranog mišljenja. U skladu s Međunarodnim revizijskim standardom 705 ili značajna neizvjesnost u vezi s događajima ili uvjetima, koja može stvarati značajnu sumnju u mogućnost subjekta da nastavi s vremenski neograničenim poslovanjem u skladu s MRevS-om 570 jesu po svojim sadržajima ključna revizijska pitanja. Međutim, u takvim okolnostima, ta pitanja neće biti opisana u Odjeljku za ključna revizijska pitanja u revizorovu izvješću. Umjesto toga, revizor će: a) izvijestiti o tom pitanju, odnosno pitanjima, u skladu s primjenjivim MRevS-om ili MRevS-ima; i b) uključiti u Odjeljku za ključna revizijska pitanja poziv na odjeljak s osno- 
vom za mišljenje s rezervom ili negativno mišljenje ili odjeljak za značajnu neizvjesnost u vezi s vremenski neograničenim poslovanjem (MRevS 701, para 15). Iako primjena tog standarda utječe na revizije financijskih izvještaja nakon 2016. godine, , ,ključna revizijska pitanja i njihov utjecaj na reviziju je još uvijek neistraženo područje“" (Segal, 2019).

Istodobno, i na razini Europske unije i njezina regulatornog okvira poduzete su mnoge inicijative koje su u konačnici rezultirale reformom revizijskog tržišta te značajnim izmjenama predložene zakonske regulative koje su posljedično implementirane u zakonodavstva svih zemalja članica Europske unije. Prije svega, donesena je Direktiva o zakonskim revizijama koja je implementirana u Zakon o reviziji koji je donesen 2017. godine. U tom smislu posebnu važnost ima Uredba koja se odnosi na zakonske revizije subjekata od javnog interesa (Uredba (EU) br. 537/2014). Direktiva i Uredba traže dodatne informacije od zakonskog revizora u pogledu revizorskog izvještaja. Između ostalog, dodatni zahtjevi koji se postavljaju pred revizore subjekata od javnog interesa odnose na navođenje: ,a) tko je ili koje je tijelo imenovalo ovlaštenog revizora, b) navodi datum imenovanja revizora i razdoblje neprekinutog angažmana (uključujući prethodna produljenja i ponovna imenovanja). Osim toga, kao potporu revizorovu mišljenju potrebno je dati i sljedeće informacije: i) opis najznačajnijih procijenjenih rizika bitno pogrešnog prikazivanja, ii) sažetak odgovora na te rizike te iii) ako je relevantno, najznačajnija zapažanja o tim rizicima. Osim toga, objašnjava do koje mjere zakonska revizija smatra sposobnim otkriti nepravilnosti, uključujući prijevaru, potvrđuje da je revizorsko mišljenje dosljedno, s dodatnim izvješćem revizijskom odboru, te izjavljuje da prilikom obavljanja revizije nisu pružene zabranjene nerevizorske usluge i da su ovlašteni revizori ili revizorska društva tijekom obavljanja revizije (ostali) neovisni o subjektu koji je predmet revizije te navodi sve usluge, uz zakonsku reviziju, koje su ovlašteni revizor ili revizorsko društvo pružili subjektu koji je predmet revizije i društvima koja su pod njegovom kontrolom, a koje nisu bile priopćene u izvješću o upravljanju ili financijskim izvještajima“" . U tom smislu, donošenje revizijske Direktive i Uredbe rezultiralo je uvođenjem njihovih odredbi u nacionalne zakone država članica Europske unije tako da se sadržaj revizorova izvješća, uz strukovni okvir koji je propisan Međunarodnim revizijskim standardima, proširio na informacije temeljene na Uredbi (EU) br. 537/2014. Osim toga, svaka država članica ima mogućnost proširiti strukturu i sadržaj revizorova izvješća, što je u nacionalnom zakonodavstvu implementirano kroz Zakon o računovodstvu. ${ }^{2}$ Sve dodatne informacije o obavljenoj reviziji korisne su i stvaraju značajan informacijski potencijal za brojna znanstvena i stručna istraživanja.

Uredba (EU) br. 537/20, 14 EUROPSKOG PARLAMENTA I VIJEĆA od 16. travnja 2014. o posebnim zahtjevima u vezi zakonske revizije subjekata od javnog interesa i stavljanju izvan snage Odluke Komisije 2005/909/EZ dostupno na: https://eur-lex.europa.eu/legalcontent/HR/TXT/PDF/?uri=CELEX:32014R0537\&from=ENžFRC

2 Zakon o računovodstvu čl. 20. (Narodne novine br.120/16, 116/18) 


\section{PREGLED PROVEDENIH ISTRAŽIVANJA O UČINCIMA OBJAVLJIVANJA KLJUČNIH REVIZIJSKIH PITANJA U IZVJEŠĆU NEOVISNOG REVIZORA}

Međunarodni revizijski standard 701 - Ključna revizijska pitanja, koji se primjenjuje za revizije financijskih izvještaja nakon prosinca 2016., godine imao je za cilj povećati komunikacijsku i informativnu vrijednost izvješća neovisnog revizora, pri čemu se najznačajniji zahtjev odnosi na činjenicu da revizor mora izvještavati o ključnim revizijskim pitanjima te revizijskim postupcima i procedurama kojima je dokazao realnost i objektivnost pojedinih računa u temeljnim financijskim izvještajima. Pri tome, ključna revizijska pitanja su sličnog sadržaja kao „kritična revizijska pitanja“ (engl. critical audit matters $K A M$,) kako to prepoznaje američki Odbor za nadzor nad računovodstvom javnih poduzeća (engl. Public Company Accounting Standards Board - PCAOB). U francuskom području ova se pitanja nazivaju „opravdanost naših procjena“ (engl. justification of our assessments - JOAs), a u britanskom području ,rizici od značajnih pogrešnih iskaza“ (engl. risk od material misstatements - RMMs). U tom smislu, od početka njihove primjene brojna su istraživanja usmjerena $\mathrm{k}$ tome da se dokaže komunikacijska i informativna vrijednost revizorovih izvješća.

\subsection{Pregled istraživanja koji potvrđuje doprinos objavljivanja ključnih revizijskih pitanja transparentnosti financijskog izvještavanja}

Prezentiranje ključnih revizijskih pitanja i eksterna revizija trebaju biti okarakterizirani kao glavni instrument za poboljšanje povjerenja dioničara u financijske izvještaje nakon ove financijske, ali i gospodarske krize uzrokovane pandemijom bolesti COVID-19. Predstavljanje i objavljivanje ključnih revizijskih pitanja trebalo bi poboljšati informacijsku vrijednost i korisnost revizorova izvješća, ali bi isto tako trebalo imati utjecaja na kvalitetu djelovanja revizora i menadžera. U tom smislu, provedena su istraživanja kako bi se utvrdio utjecaj promjena karakteristika izvješća neovisnog revizora na kvalitetu revizije i revizijske naknade. Pri tome se ispitivala kvaliteta revizije izmjerena prema apsolutnim abnormalnim obračunskim veličinama i naknadama za reviziju na uzorku revizijskih klijenata s Novog Zelanda. Autori Li, Hay \& Lau (2019) zaključili su kako je nakon proširenja sadržaja i opsega revizorskih izvješća došlo do poboljšanja kvalitete revizije, što je potvrđeno smanjenjem apsolutnih obračunskih veličina. Isto tako, dokazano je da je došlo do značajnog povećanja naknada za reviziju (Li, Hay \& Lau 2019) .

Dosadašnja istraživanja fokusirala su se na utjecaj objavljivanja ključnih revizijskih pitanja na sljedeće dionike: 1) dioničare (percepcije investitora na odgovornost i legitimitet revizije, vrijednost i relevantnost odluka investitora), 2) vjerovnike (ugovorne odredbe o zajmovima), 3) eksterne revizore (revizijske procedure i revizijske naknade), 4) upravne, odnosno nadzorne odbore (zarade menadžmenta) i 5) ostale dionike (informacijska vrijednost za dobavljače i kupce) (Velte \& Issa, 2019).

U tom smislu, istraživanja su provedena kako bi istražila posljedice objavljivanja ključnih revizijskih pitanja na ponašanje investitora, odgovore revizora, revizorove procjene i odgovornosti, kao i menadžmentove odgovornosti (Gold \& Heilmann, 2019). Ipak, ključna revizijska pitanja nisu samo u funkciji poboljšanja transparentnosti za korisnike financijskih 
izvještaja već poboljšavaju i ponašanje menadžmenta u procesu financijskog izvještavanja. $\mathrm{U}$ tom smislu istraživanja su usmjerena $\mathrm{k}$ tome može li objavljivanje ključnih revizijskih pitanja umanjiti agresivno financijsko izvještavanje menadžmenta (Gold et al., 2020). Dokazano je da menadžment nastoji reducirati odluke o agresivnom financijskom izvještavanju kada su objavljena ključna revizijska pitanja u revizorovu izvješću, u odnosu na situaciju kada ključna revizijska pitanja nisu objavljena (Gold et al., 2020).

Istraživanje o tome utječu li specifičnosti klijenta na broj objavljenih ključnih revizijskih pitanja, pokazalo je da postoji pozitivna korelacija između broja objavljenih revizijskih pitanja i kompleksnosti klijenta te činjenice da se radi o klijentu tzv. velike četvorke. Osim toga, revizijske naknade i modificiranost revizorova mišljenja u negativnoj su korelaciji s brojem objavljenih ključnih revizijskih pitanja (Ferreira \& Morais, 2019).

Isto tako, neka su se istraživanja usmjerila na utjecaj izvješća neovisnih revizora na odluke investitora na financijskom tržištu o tome treba li zadržati ili prodati dionice (Robu \& Robu 2015). Pokazno je da pouzdanost revizorova izvješća i revizijskog mišljenja ovisi o tome jesu li financijski izvještaji revidirani od strane velike četvorke ili nisu. Drugim riječima, pokazano je da za društva koja su listana na burzi u Rumunjskoj predstavljene financijske informacije imaju značajan utjecaj na profitabilnost dionice u ovisnosti o mišljenju koje je izraženo u izvješću neovisnog revizora te pripadnost revizora koji je to mišljenje izdao velikoj četvorki ili ostalim revizijskim društvima. Dokazano je da su financijski rezultati u pozitivnoj ovisnosti s rezultatima predstavljenim u financijskim izvještajima. Isto tako, investitori su oprezniji ovisno o tome je li revizorovo mišljenje izdalo društvo koje pripada velikoj četvorki u odnosu na ostala revizorska društva (Robu \& Robu 2015).

$\mathrm{Na}$ temelju analize sekundarnih podataka Wuttichindanon i Issarawornrawanich (2020) istraživali su povezanost između broja ključnih revizijskih pitanja i tri skupine čimbenika, i to: 1) svojstva revizora, 2) mehanizama korporativnog upravljanja i 3) karakteristika poduzeća. Pokazano je da značajni čimbenici koji doprinose objavljivanju ključnih revizijskih pitanja uključuju rizik parnice revizora, složenost društva, profitabilnost i vrstu djelatnosti. Naime, društva koja revidira velika četvorka, koja imaju mnoge podružnice te ona koja djeluju u tehnološkoj, građevinskoj i financijskoj industriji objavljuju veći broj ključnih revizijskih pitanja dok visokoprofitabilna društva u revizorovim izvješćima imaju objavljen manji broj ključnih revizijskih pitanja. Osim toga, pokazano je kako je broj ključnih revizijskih pitanja u pozitivnoj korelaciji s brojem neovisnih direktora. Drugim riječima, dokazano je da što su jači mehanizmi korporativnog upravljanja, veći je broj objavljenih ključnih revizijskih pitanja (Wuttichindanon \& Issarawornrawanich 2020).

Pratoomsuwan \& i Yolrabil (2020) proveli su istraživanje o učincima objavljivanja ključnih revizijskih pitanja te odgovornosti revizora u slučajevima prijevara i pogreški. Na uzorku ispitanika utvrđeno je da je revizorova odgovornost percipirana kao značajnija kada se povezuje s pogreškom u odnosu na prijevaru. Uz to, rezultati pokazuju kako objavljivanja ključnih revizijskih pitanja smanjuju odgovornost revizora samo u slučajevima prijevare, a ne i pogreške. U konačnici, potvrđeno je da objavljivanje ključnih revizijskih pitanja smanjuje negativne reakcije korisnika, odnosno smanjuje odgovornost revizora (Pratoomsuwan $\&$ Yolrabil, 2020).

Na temelju istraživanja relevantne literature predložene su određene smjernice za revizijsku praksu. Prvo, revizori trebaju biti svjesni da korisnici obraćaju pozornost na objavljena ključna revizijska pitanja i u tom smislu revizori trebaju posebnu pozornost usmjeriti 
na broj objavljenih ključnih revizijskih pitanja, kao i njihov sadržaj koji objavljuju u revizorovim izvješćima. Isto tako, objavljivanjem ključnih revizijskih pitanja mogu se izbjeći negativne posljedice koncepta razumnog uvjerenja te se može dati preciznija informacija korisnicima. Regulatori trebaju posebnu pažnju usmjeriti na pojašnjenje informacija koje se pojavljuju kao ključna revizijska pitanja (Gold \& Heilmann, 2019).

\subsection{Pregled istraživanja koja ne potvrđuju doprinos objavljivanja ključnih revizijskih pitanja transparentnosti financijskog izvještavanja}

Rezultati provedenih istraživanja o utjecaju objavljivanja ključnih revizijskih pitanja na kvalitetu revizije i kvalitetu financijskog izvještavanja nisu jednoznačni. Naime, iako postoje brojne potvrde da su se dogodile reakcije menadžmenta u pogledu reduciranja upravljanja zaradama (engl management earnings), većina znanstvenih istraživanja ne dokazuje značajne promjene u revizorovu ponašanju. Nadalje, rezultati istraživanja pokazuju neznačajne rezultate u pogledu ponašanja dioničara u okviru agencijske i bihevioralne teorije. Istraživanje o tome kako primjena novih revizijskih standarda u kojima je nužno uključivanje ključnih revizijskih pitanja utječe na investitore (reakcije na tržištu kapitala) i kvalitetu revizije pokazalo je da nema značajnih koristi. Točnije, tržište nije značajno reagiralo na objavljivanje ključnih revizijskih pitanja te nije dokazana veća kvaliteta revizije (Li, 2017).

Istraživanja provedena u Velikoj Britaniji pokazuju kako novi standard proširuje model revizijskog izvještavanja zahtijevajući od revizora da otkriju rizike značajnih pogrešnih prikazivanja (engl. risk of material misstatement - RMM) koji su imali najveći učinak na reviziju financijskih izvještaja. Isto istraživanje pokazalo je zašto ulagači ne smatraju da su ova dodatna otkrivanja rizika revizora informativna (Lennox, Schmidt, Thompson 2021). Autori su pošli od sljedećih pretpostavki: 1) informacije o rizicima, kako ih predstavlja revizor, jesu informativne, ali investitori nisu odmah na njih reagirali, 2) revizor propušta objaviti značajne rizike financijskog izvještavanja jer je sve značajne rizike identificirao i uklonio tijekom provođenja dokaznih revizijskih postupaka i 3) investitori su već upoznati s rizicima financijskog izvještavanja kao posljedica ranijih objava u godišnjim izvješćima ili prijašnjih objava. Nadalje, istraživanje je pokazalo kako promjene tržišnih reakcija investitora nisu posljedica objavljenih rizika značajnog pogrešnog prikazivanja u revizorovim izvješćima. Isto tako, potvrđeno je da tržišne reakcije nisu posljedica objavljivanja revizora koji otkrivaju rizike financijskog izvještavanja. Osim toga dani su dokazi koji potvrđuju da prilikom objavljivanja rizika značajnog pogrešnog prikazivanja u financijskim izvještajima nedostaje informativni sadržaj jer su investitori već bili obaviješteni o rizicima financijskog izvještavanja prije nego što su ih revizori otkrili u proširenim revizorskim izvještajima (Lennox, Schmidt, Thompson 2021). I druga istraživanja provedena u Velikoj Britaniji pokazuju da objavljivanje ključnih revizijskih pitanja nije značajno informativno za investitore (Gutierrez et al., 2018).

Istraživanje Weerapong \& Sarapaivanich (2020) potvrdilo je slabu vezu između objavljivanja ključnih revizijskih pitanja i unaprjeđenja kvalitete revizije jer revizori više truda ulažu u reviziju te temeljitije obavljaju reviziju nakon primjene standarda koji zahtijevaju objavu ključnih revizijskih pitanja. Međutim, broj objavljenih ključnih revizij- 
skih pitanja, kao i najčešći tipovi objavljenih ključnih revizijskih pitanja, nisu povezani s kvalitetom revizije (mjereno diskrecijskim razgraničenjima). Jedino su predstavljena ključna revizijska pitanja povezana s akvizicijama informativnija jer ova vrsta objave implicira veću vjerojatnost financijskih prepravljanja u sljedećoj godini (Weerapong \& Sarapaivanich, 2020).

Opće je poznata teza kako izvješće neovisnog revizora služi kao instrument smanjenja jaza očekivanja između revizije i svih njezinih inherentnih ograničenja te korisnika financijskih izvještaja. U tom smislu interesantno je ispitati povezanost objavljivanja ključnih revizijskih pitanja i njihov utjecaj na smanjenje jaza očekivanja od revizije. Coram \& Wang (2019) pokazali su da objavljivanje ključnih revizijskih pitanja samo po sebi nije smanjilo jaz očekivanja korisnika revizora. Naprotiv, pokazali su da se jaz u očekivanjima povećao kod mjera povezanih s percepcijom pouzdanosti revidiranih financijskih izvještaja kada je revizorovo izvješće uključivalo ključno revizijsko pitanje koje slijedi precizan računovodstveni standard. U konačnici, autori su zaključili da primjena promjene izvještavanja može imati i neke neželjene posljedice (Coram \&Wang, 2019). Isto tako, istraživanje koje je proveo Segal (2019) pokazalo je da objavljivanje ključnih revizijskih pitanja nije povećalo transparentnost revizorova izvješća, čak štoviše klijenti su zanemarivali informacije o ključnim revizijskim pitanjima (Segal, 2019).

Međutim, do drugačijeg je zaključka došao Velte (2019) koji je razmatrao stručnost članova revizijskog odbora te njihovu mogućnost da čitaju i razumiju ključna revizijska pitanja. Polazeći od agencijske teorije kako revizorova izvješća smanjuju informacijsku asimetriju između korisnika i menadžmenta na temelju uzoraka britanskih društava koja kotiraju na burzi, pokazao je da postoji pozitivna korelacija između stručnosti članova revizijskih odbora i ,čitljivosti“" ključnih revizijskih pitanja. Pri tome se autor oslanjao na popularne mjere čitljivosti (engl. Flesch Reading Ease and Fog Index) (Velte, 2019).

Značajan segment djelovanja revizora je i ocjena računovodstvenih procjena u financijskim izvještajima. $\mathrm{S}$ obzirom na to da računovodstvene procjene u velikoj mjeri mogu utjecati na financijski položaj i uspješnost poslovanja, koji su predstavljeni u financijskim izvještajima, sasvim sigurno je da su kao takvi uvijek pod posebnim razmatranjem revizora. Istraživanje koje je proveo Lue (2020) pokazalo je da se 44,1 \% svih objavljenih ključnih revizijskih pitanja odnosi na računovodstvene procjene fer vrijednosti i gubitka od umanjenja. Ipak, korištenje računovodstvenih procjena u društvima o kojima su izvijestili revizori kao ključna revizijska pitanja nije povećalo vrijednosti ili prediktivnu vrijednost prijavljene zarade (Lau, 2020).

Na temelju svega iznesenog može se zaključiti kako su potrebna daljnja istraživanja u području utjecaja objavljivanja ključnih revizijskih pitanja na kvalitetu revizije i korisnost njihova objavljivanja za sve interesno utjecajne skupine u procesu korporativnog upravljanja. U tom smislu preporučavaju se daljnja istraživanja u tom području, koja će biti usmjerena na ključne dionike financijskog izvještavanja i to dioničare, vjerovnike, eksterne revizore i ostale dionike u procesu financijskog izvještavanja, kao i istraživanja po pojedinim zemljama. 


\section{PRELIMINARNI REZULTATI ISTRAŽIVANJA O OBJAVLJIVANJU KLJUČNIH REVIZIJSKIH PITANJA NA PRIMJERU IZDAVATELJA U REPUBLICI HRVATSKOJ}

Dosadašnja istraživanja pokazala su kako se najčešća područja koja revizori ističu kao ključna revizijska pitanja odnose na: priznavanje prihoda, vrijednosno usklađivanje (umanjenje) potraživanja; umanjenje vrijednosti goodwilla i ostale nematerijalne imovine, vrednovanje zaliha, vrednovanje investicija, razgraničenja i rezerviranja, umanjenje vrijednosti nekretnina, zemljišta i opreme, vrednovanje imovine po fer vrijednosti (Sahyda, 2019). Osim toga, na uzorku izvještaja o ključnim revizijskim pitanjima najčešći razlog zašto je nešto okarakterizirano kao ključno revizijsko pitanje značajne su procjene menadžmenta (engl. significant management judgements). Istraživanje provedeno na uzorku kompanija iz Kine potvrdilo je da su najčešća ključna revizijska pitanja vezana uz: priznavanje prihoda, mjerenje fer vrijednosti, umanjenje imovine, odgođena porezna imovina, porezi i transakcije s povezanim stranama (Li, 2017).

Na uzorku nizozemskih listajućih društava ključna revizijska pitanja uključivala su: pripajanje i otuđivanje operativnih aktivnosti (engl. acquistion and disposal of operating activities), poreze (odgođeni i tekući), vrednovanje goodwilla, vrednovanje nekretnina, rizike prijevare kod priznavanje prihoda, primanja zaposlenih, vrednovanje druge imovine, menadžmentovo zaobilaženje sustava internih kontrola, tužbe, derivate, popuste na kupnju, IT okruženje, vrednovanje obveza, novac i ostalo (Pwc, 2014).

U cilju analize strukture i sadržaja ključnih revizijskih pitanja provedeno je istraživanje objava u izvješću neovisnog revizora na uzorku izdavatelja na Zagrebačkoj burzi. Pregledana su izvješća neovisnih revizora za 108 izdavatelja čiji su financijskih izvještaji dostupni na Zagrebačkoj burzi. Iz uzorka su isključeni izdavatelji koji su specifični po nekim karakteristikama, primjerice, Ministarstvo financija kao proračunski korisnik, kao i kreditne institucije te investicijski fondovi jer su struktura i sadržaj financijskih izvještaja specifični pa u tom kontekstu nisu usporedivi s ostalim izdavateljima koji djeluju u realnom sektoru. Naime, objavljivanje ključnih revizijskih pitanja ovisi o karakteristikama industrijske koncentracije. Primjerice, u financijskoj industriji ključna revizijska pitanja usmjerena su na fer vrijednost financijske imovine, umanjenje financijske imovine, rezerviranja za zajmove i anticipirane gubitke te konsolidaciju povezanih osoba (Li, 2017). Osim toga, za neke izdavatelje nije bilo dostupnih informacija jer su uključeni na burzi izvan godine promatranja ili se radi o dionicama koje nisu aktivne te se njima nije trgovalo. $\mathrm{U}$ tom smislu svakako proizlaze i ograničenja ovog istraživanja, odnosno preporuke za daljnje istraživanje u kojem bi se analizirale specifičnosti objava u izvješću neovisnog revizora, $\mathrm{s}$ obzirom na to da se i revizijski postupci u velikoj mjeri razlikuju u pogledu djelatnosti kojom se revidirani klijent bavi. Osim toga, analizirana su izvješća neovisnih revizora za financijske izvještaje čija je poslovna godina uključivala financijske izvještaje za 2019. godinu.

Provedeni pregled izvješća neovisnih revizora pokazuje da se većina revizija subjekata od javnog interesa uskladila sa zahtjevima Međunarodnih revizijskih standarda koji zahtijevaju objavljivanje ključnih revizijskih pitanja, iako revizori imaju različite pristupe u objavljivanju broja i prirode ključnih revizijskih pitanja, kao i objavljivanje materijalnosti korištene u revizijskom procesu. Značajan broj revizora koji revidiraju izdavatelje ne pripada skupini velike četvorke kako je prikazano u tablici 1. 
Tablica 1. Broj izdanih izvješća revizora po kriteriju veličine revizorskog društva

\begin{tabular}{|l|l|r|}
\hline \multicolumn{1}{|c|}{ VRSTA REVIZORA } & $\mathrm{N}$ & $\%$ \\
\hline „VELIKA ČETVORKA“ & 48 & $57,14 \%$ \\
\hline OSTALI REVIZORI & 36 & $42,86 \%$ \\
\hline UKUPNO & 84 & $100,00 \%$ \\
\hline
\end{tabular}

Izvor: autor

Tablica 2. Vrste izdanih mišljenja u izvješću neovisnog revizora

\begin{tabular}{|l|c|c|}
\hline VRSTE MIŠLJENJA & $\mathrm{N}$ & $\%$ \\
\hline POZITIVNO & 61 & $72,62 \%$ \\
\hline S REZERVOM & 22 & $26,19 \%$ \\
\hline NEGATIVNO & 0 & $0,00 \%$ \\
\hline SUZDRŽANO & 1 & $1,19 \%$ \\
\hline Ukupno & 84 & $100 \%$ \\
\hline
\end{tabular}

Izvor: autor

Isto tako, valja istaknuti kako je značajan broj izdavatelja dobio kvalificirano mišljenje, odnosno mišljenje s rezervom (tablica 2.). Suzdržano mišljenje je izdano zbog sumnje u narušenu pretpostavku vremenske neograničenosti poslovanja. Rezultat je to činjenice da postoje brojne mogućnosti unaprjeđenja kvalitete financijskog izvještavanja kod izdavatelja.

Uobičajeno se ističe kako je temeljni zadatak revizora prikazati da imovine ima barem toliko koliko je zapisano u financijskim izvještajima, i da su sve obveze uključene u financijske izvještaje. U tom smislu uobičajeno se ističe kako su prihodi od prodaje najrizičnija stavka u financijskim izvještajima, što je dokazano činjenicom da je to ključno revizijsko pitanje koje se pojedinačno najčešće pojavljuje u izvješćima neovisnog revizora među izdavateljima. Brojni problemi u priznavanju prihoda uzrok su velikih korporativnih skandala koji nisu zaobišli ni revizijsku profesiju, a čiji je konačan rezultat bio implementiranje Međunarodnog standarda financijskog izvještavanja MSFI 15 - Priznavanje prihoda s kupcima. Ključnim revizijskim pitanjima vezanima uz priznavanje prihoda od prodaje svakako treba pridodati i ključna revizijska pitanja vezana uz priznavanje i vrednovanje potraživanja od kupaca s obzirom na to da se radi o povezanim računima u računovodstvenome smislu. 
Tablica 3. Ključna revizijska pitanja u izvješćima neovisnih revizora na uzorku izdavatelja na Zagrebačkoj burzi

\begin{tabular}{|c|c|c|c|}
\hline PODRUČJE & KLJUČNO REVIZIJSKO PITANJE & $\mathbf{N}$ & $\%$ \\
\hline $\begin{array}{l}\text { PRIHODI } \\
\text { (28 objava) }\end{array}$ & $\begin{array}{l}\text { Prihodi od prodaje (MSFI } 15 \text { - Priznavanje prihoda s } \\
\text { kupcima) }\end{array}$ & 28 & $19,31 \%$ \\
\hline \multirow[t]{2}{*}{$\begin{array}{l}\text { NEMATERIJALNA } \\
\text { IMOVINA } \\
\text { (5 objava) }\end{array}$} & $\begin{array}{l}\text { Nematerijalna imovina i umanjenje vrijednosti } \\
\text { (kapitalizacija prava na sadržaj i imovina s pravom } \\
\text { korištenja) }\end{array}$ & 4 & $2,76 \%$ \\
\hline & Goodwill & 1 & $0,69 \%$ \\
\hline \multirow[t]{4}{*}{$\begin{array}{l}\text { MATERIJALNA } \\
\text { IMOVINA } \\
\text { (34 objave) }\end{array}$} & $\begin{array}{l}\text { Nekretnine postrojenja i oprema (promjena } \\
\text { računovodstvene politike, procjena korisnog vijeka } \\
\text { upotrebe, pokazatelji umanjenja vrijednosti, kapitalizacija } \\
\text { troškova te nadoknadivost dugotrajne imovine) u } \\
\text { poslovnom segmentu turizma }\end{array}$ & 17 & $11,72 \%$ \\
\hline & $\begin{array}{l}\text { Nekretnine postrojenja i oprema (promjena } \\
\text { računovodstvene politike, procjena korisnog vijeka } \\
\text { upotrebe, pokazatelji umanjenja vrijednosti, fer } \\
\text { vrijednosti ulaganja, kapitalizacija troškova te } \\
\text { nadoknadivost dugotrajne imovine) ostale djelatnosti }\end{array}$ & 12 & $8,28 \%$ \\
\hline & Vrednovanje i umanjenje vrijednosti ulaganja u brodove & 3 & $2,07 \%$ \\
\hline & Procjena fer vrijednosti zemljišta & 2 & $1,38 \%$ \\
\hline $\begin{array}{l}\text { NAJMOVI }(9 \\
\text { objava) }\end{array}$ & $\begin{array}{l}\text { Računovodstvo najmova, primjena MSFI } 16 \text { i povezane } \\
\text { objave }\end{array}$ & 9 & $6,21 \%$ \\
\hline $\begin{array}{l}\text { DUGOROČNA } \\
\text { POTRAŽIVANJA } \\
(2 \text { objave) }\end{array}$ & Ostala potraživanja i dugoročna potraživanja & 2 & $1,38 \%$ \\
\hline \multirow[t]{2}{*}{$\begin{array}{l}\text { ZALIHE } \\
\text { (12 objava) }\end{array}$} & $\begin{array}{l}\text { Vrednovanje zaliha (proizvodnja u toku i gotovi } \\
\text { proizvodi) i povezane objave u financijskim izvještajima }\end{array}$ & 11 & $7,59 \%$ \\
\hline & Inventura zaliha & 1 & $0,69 \%$ \\
\hline \multirow{6}{*}{$\begin{array}{l}\text { FINANCIJSKA } \\
\text { IMOVINA }(23 \\
\text { objave })\end{array}$} & $\begin{array}{l}\text { Financijska imovina - povezane osobe (pozajmice } \\
\text { povezanom društvu) }\end{array}$ & 6 & $4,14 \%$ \\
\hline & Ulaganja u ovisna društva (umanjenje vrijednosti) & 9 & $6,21 \%$ \\
\hline & Utjecaj prve primjene - MSFI 9 - Financijski instrumenti & 4 & $2,76 \%$ \\
\hline & Klasifikacija i vrednovanje ulaganja u zajedničke pothvate & 1 & $0,69 \%$ \\
\hline & Dani zajmovi & 2 & $1,38 \%$ \\
\hline & Regresne mjenice & 1 & $0,69 \%$ \\
\hline $\begin{array}{l}\text { POTRAŽIVANJA } \\
\text { OD KUPACA } \\
(4 \text { objave) }\end{array}$ & Vrednovanje potraživanja od kupaca & 4 & $2,76 \%$ \\
\hline \multirow{2}{*}{$\begin{array}{l}\text { KAPITAL } \\
(2 \text { objave })\end{array}$} & Revalorizacijske rezerve & 1 & $0,69 \%$ \\
\hline & \begin{tabular}{|l|} 
Rezerve $\mathrm{u}$ promjenama glavnice \\
\end{tabular} & 1 & $0,69 \%$ \\
\hline \multirow{3}{*}{$\begin{array}{l}\text { OBVEZE } \\
(9 \text { objava) }\end{array}$} & Provjera točnosti i sveobuhvatnosti obveza & 5 & $3,45 \%$ \\
\hline & Obveze za izdane mjenice & 2 & $1,38 \%$ \\
\hline & Neobračunate i neiskazane zatezne kamate & 2 & $1,38 \%$ \\
\hline $\begin{array}{l}\text { DUGOROČNA } \\
\text { REZERVIRANJA } \\
(6 \text { objava) }\end{array}$ & $\begin{array}{l}\text { Dugoročna rezerviranja za sudske sporove, primanja } \\
\text { zaposlenih, procjene jamstava te ukidanje rezerviranja }\end{array}$ & 6 & $4,14 \%$ \\
\hline
\end{tabular}


Nastavak tablice 3.

\begin{tabular}{|l|l|r|r|}
\hline PODRUČJE & KLJUČNO REVIZIJSKO PITANJE & N & \multicolumn{1}{c|}{$\%$} \\
\hline \multirow{5}{*}{$\begin{array}{l}\text { OSTALO objava) } \\
\text { (11 }\end{array}$} & Odgođena porezna obveza & 1 & $0,69 \%$ \\
\cline { 2 - 4 } & Procjena vrijednosti dobitka od povoljne kupnje & 1 & $0,69 \%$ \\
\cline { 2 - 4 } & Vremenska neograničenost poslovanja & 1 & $2,76 \%$ \\
\cline { 2 - 4 } & Ugovor o upravljanju i potraživanjima od kupaca & 1 & $0,69 \%$ \\
\cline { 2 - 4 } & $\begin{array}{l}\text { Potpunost i točnost stavki odvojenog izvještaja o } \\
\text { sveobuhvatnoj dobiti te odvojenog izvještaja o } \\
\text { financijskom položaju }\end{array}$ & 1 & $0,69 \%$ \\
\cline { 2 - 4 } & $\begin{array}{l}\text { Nemogućnost pribavljanja revizijskih dokaza za jedinicu } \\
\text { u inozemstvu }\end{array}$ & 1 & $0,69 \%$ \\
\cline { 2 - 4 } & $\begin{array}{l}\text { Procjene korištene u izračunu obveza iz ugovora o } \\
\text { osiguranju i test adekvatnosti obveza (LAT) }\end{array}$ & 1 & $0,69 \%$ \\
\cline { 2 - 4 } & $\begin{array}{l}\text { Iskazivanje najmova od povezanih društava starijih od } \\
\text { 365 dana za koje ne postoji sredstvo osiguranja naplate }\end{array}$ & $\mathbf{1 4 5}$ & $\mathbf{1 0 0} \%$ \\
\hline
\end{tabular}

Izvor: autor

S obzirom na značajan udio materijalne imovine u strukturi ukupne imovine, značajan broj ključnih revizijskih pitanja odnosi se na nekretnine postrojenja i opremu. Iz pregleda istraživanja može se zaključiti kako su revizori problematizirali prilikom objavljivanja ključnih revizijskih pitanja, brojne računovodstvene procjene, od procjene vijeka upotrebe nekretnina postrojenja i opreme, nadoknadivosti imovine te indikatore umanjenja vrijednosti do nadoknadivosti imovine. S obzirom na specifičnu strukturu imovine izdavatelja u djelatnosti turizam, posebno su istaknuta ključna revizijska pitanja vezana uz nekretnine postrojenja i opreme izdavatelja u segmentu turizam.

Dana 1. siječnja 2019. godine na snagu je stupio Međunarodni standard financijskog izvještavanja 16 - Najmovi (MSFI 16) pa su tom smislu najmovi predstavljali ključno revizijsko pitanje u nekoliko slučajeva. Primjena usvojenog standarda zahtijevala je značajne prilagodbe u strukturi imovine pa je to svakako nešto što je posebno potrebno naglasiti. Međunarodni revizijski standardi naglašavaju kako promjena standarda financijskog izvještavanja predstavlja rizičnu stavku u financijskim izvještajima s obzirom na prilagodbe koje je potrebno poduzeti kako bi se implementirala nova primjena. $U$ tom smislu u analizi ključnih revizijskih pitanja narednih godina ovo pitanje ne bi trebalo biti toliko značajno.

Značajan broj ključnih revizijskih pitanja odnosi se na priznavanje i vrednovanje dugotrajne i kratkotrajne financijske imovine. S obzirom na brojne pretpostavke koje je potrebno uvažavati prilikom procjene financijske imovine opravdana je usmjerenost revizora na ova pitanja. Izvještavanje o ključnim revizijskim pitanjima može biti doista izazov. Prije svega to se odnosi na one elemente koji imaju značajnu vrijednost imovine koja je podložna procjenama i to u onom dijelu gdje ne samo da treba provoditi testove na umanjenje, već tamo gdje je svaki element vrednovanja ovisan o pretpostavci koja je vrlo osjetljiva na promjenu vrijednosti.

Ukoliko je revizor izdao modificirano mišljenje, tada će navesti razlog modifikacije, te neće posebno navoditi ključna revizijska pitanja, već će se u skladu s Međunarodnim 
revizijskim standardima pozvati na odjeljak u kojem je izrazio modificirano mišljenje ili će se pozvati na vremensku neograničenost poslovanja. U tom smislu u tablici 4 klasificirana su ključna revizijska pitanja kada je revizor dao modificirano mišljenje i to mišljenje $\mathrm{s}$ rezervom.

Tablica 4: Klasifikacija razloga izdavanja modificiranog mišljenja u izvješću neovisnog revizora

\begin{tabular}{|c|c|c|c|}
\hline PODRUČJE & $\begin{array}{l}\text { KLJUČNO REVIZIJSKO PITANJE na koje se poziva } \\
\text { MODIFICIRANO MIŠLJENJE }\end{array}$ & $\mathbf{N}$ & $\%$ \\
\hline PRIHODI (8 objava) & $\begin{array}{l}\text { Prihodi od prodaje, priznavanje prihoda, ugovori s } \\
\text { kupcima (MSFI } 15 \text { - priznavanje prihoda s kupcima) }\end{array}$ & 8 & $14,81 \%$ \\
\hline $\begin{array}{l}\text { NEMATERIJALNA } \\
\text { IMOVINA (1 objava) }\end{array}$ & Nematerijalna imovina i umanjenje vrijednosti & 1 & $1,85 \%$ \\
\hline \multirow[t]{3}{*}{$\begin{array}{l}\text { MATERIJALNA } \\
\text { IMOVINA ( } 6 \text { objava) }\end{array}$} & $\begin{array}{l}\text { Vrednovanje nekretnina, postrojenja i opreme (promjena } \\
\text { računovodstvene politike, procjena korisnog vijeka } \\
\text { upotrebe te pokazatelji umanjenja vrijednosti) u poslovnom } \\
\text { segmentu turizam }\end{array}$ & 1 & $1,85 \%$ \\
\hline & $\begin{array}{l}\text { Vrednovanje nekretnina, postrojenja i opreme } \\
\text { (promjena računovodstvene politike, procjena korisnog } \\
\text { vijeka upotrebe te pokazatelji umanjenja vrijednosti, } \\
\text { nadoknadivost dugotrajne materijalne imovine) }\end{array}$ & 3 & $5,56 \%$ \\
\hline & Vrednovanje i umanjenje vrijednosti ulaganja u brodove & 2 & $3,70 \%$ \\
\hline $\begin{array}{l}\text { NAJMOVI } \\
\text { (2 objave) } \\
\end{array}$ & Računovodstvo najmova i povezane objave (MSFI 16) & 2 & $3,70 \%$ \\
\hline $\begin{array}{l}\text { DUGOROČNA } \\
\text { POTRAŽIVANJA } \\
\text { ( } 2 \text { objave) }\end{array}$ & Ostala potraživanja i dugoročna potraživanja od zakupnika & 2 & $3,70 \%$ \\
\hline \multirow[t]{2}{*}{ ZALIHE (6 objava) } & $\begin{array}{l}\text { Vrednovanje zaliha nedovršene proizvodnje i gotovih } \\
\text { proizvoda i povezane objave u financijskim izvještajima }\end{array}$ & 5 & $9,26 \%$ \\
\hline & Inventura zaliha & 1 & $1,85 \%$ \\
\hline \multirow{5}{*}{$\begin{array}{l}\text { FINANCIJSKA } \\
\text { IMOVINA } \\
\text { (12 objava) }\end{array}$} & Financijska imovina - povezane osobe & 1 & $1,85 \%$ \\
\hline & $\begin{array}{l}\text { Vrednovanje i umanjenje vrijednosti ulaganja u ovisna } \\
\text { društva (izračun očekivanih kreditnih gubitaka i } \\
\text { nadoknadivost potraživanja) }\end{array}$ & 4 & $7,41 \%$ \\
\hline & $\begin{array}{l}\text { Prva primjena Međunarodnog standarda financijskog } \\
\text { izvještavanja } 9 \text { - Financijski instrumenti (umanjenje } \\
\text { vrijednosti, fer vrednovanje) }\end{array}$ & 5 & $9,26 \%$ \\
\hline & Regresne mjenice & 1 & $1,85 \%$ \\
\hline & Dani zajmovi & 1 & $1,85 \%$ \\
\hline \multirow{2}{*}{$\begin{array}{l}\text { POTRAŽIVANJA } \\
\text { OD KUPACA } \\
(2 \text { objave })\end{array}$} & Ugovor o upravljanju i potraživanjima od društva & 1 & $1,85 \%$ \\
\hline & Vrijednosno usklađivanje potraživanja od kupaca & 1 & $1,85 \%$ \\
\hline \multirow[t]{2}{*}{ KAPITAL ( 2 objave) } & Revalorizacijske rezerve & 1 & $1,85 \%$ \\
\hline & Rezerve u promjenama glavnice & 1 & $1,85 \%$ \\
\hline
\end{tabular}


Nastavak tablice 3.

\begin{tabular}{|l|l|r|c|}
\hline \multirow{2}{*}{ PODRUČJE } & $\begin{array}{l}\text { KLJUČNO REVIZIJSKO PITANJE na koje se poziva } \\
\text { MODIFICIRANO MIŠLJENJE }\end{array}$ & $\mathbf{N}$ & $\mathbf{\%}$ \\
\hline \multirow{2}{*}{ OBVEZE (5 objava) } & Provjera točnosti i sveobuhvatnosti obveza & 1 & $1,85 \%$ \\
\cline { 2 - 4 } & $\begin{array}{l}\text { Zatezne kamate na posudbe (neobračunate i neiskazane } \\
\text { zatezne kamate) }\end{array}$ & 3 & $5,56 \%$ \\
\cline { 2 - 4 } & Obveze za izdane obveznice & 1 & $1,85 \%$ \\
\hline \multirow{2}{*}{$\begin{array}{l}\text { DUGORERVIRANJA } \\
\text { (2 objave) }\end{array}$} & $\begin{array}{l}\text { Nepredviđene obveze - jamstva u korist financijskih } \\
\text { institucija }\end{array}$ & 1 & $1,85 \%$ \\
\cline { 2 - 4 } OSTALO (6 objava) & Rezerviranja za primanja zaposlenih & 1 & $1,85 \%$ \\
\cline { 2 - 4 } & Odgođena porezna obveza & 1 & $1,85 \%$ \\
\cline { 2 - 4 } & $\begin{array}{l}\text { Vremenska neograničenost poslovanja } \\
\text { Potpunost i točnost stavki odvojenog izvještaja o } \\
\text { sveobuhvatnoj dobiti te odvojenog izvještaja o } \\
\text { financijskom položaju, koji su ostvareni sukladno } \\
\text { inozemnom poslovanju }\end{array}$ & 1 & $3,70 \%$ \\
\cline { 2 - 4 } & $\begin{array}{l}\text { Nemogućnost pribavljanja revizijskih dokaza za radnu } \\
\text { jedinicu u inozemstvu }\end{array}$ & 1 & $1,85 \%$ \\
\cline { 2 - 4 } & $\begin{array}{l}\text { Iskazivanje najmova od povezanih društava starijih od } 365 \\
\text { dana za koja ne postoji sredstvo osiguranja naplate }\end{array}$ & 1 & $1,85 \%$ \\
\cline { 2 - 4 } & UKUPNO & $\mathbf{5 4}$ & $\mathbf{1 0 0} \%$ \\
\hline
\end{tabular}

Izvor: autor

Sagledavajući razloge zbog kojih je revizor izdao modificirano mišljenje može se istaknuti kako je najveći broj modifikacije mišljenja odnosno mišljenja s rezervom povezano $\mathrm{s}$ iskazivanjem prihoda te iskazivanjem financijske imovine. S obzirom na to da je svaki element priznavanja i vrednovanja financijske imovine podložan značajnoj promjeni vrijednosti, revizori su se prvenstveno pozivali na prvu primjenu Međunarodnog standarda financijskog izvještavanja 9 - Financijski instrumenti kao i vrednovanje te umanjenje vrijednosti ulaganja u ovisna društva.

\section{ZAKLJUČAK}

Rad je imao za cilj kritički sagledati doprinose li dodatne informacije u izvješću neovisnog revizora njihovim korisnicima. U tom smislu napravljen je pregled literature o utjecaju objavljivanja ključnih revizijskih pitanja na kvalitetu financijskog izvještavanja i kvalitetu revizije. Pri analizi dostupnih istraživanja zaključeno je da postoji mnogo prostora za daljnje istraživanje u ovom području jer rezultati dosada provedenih istraživanja nisu jednoznačni. Polazeći od pretpostavke da objavljivanje ključnih revizijskih pitanja doprinosi kvaliteti financijskog izvještavanja, pokazano je da postoje brojni dokazi kako su dodatni zahtjevi regulatora utjecali na to da revizor objavljuje mnoge korisne informacije kojima dokazuje kvalitetu obavljene revizije. S druge strane, s obzirom na inherentna ograničenja koja revizijski posao nosi za sobom, postoje i istraživanja koja nisu jednoznačno dokazala vezu između objavljivanja ključnih revizijskih pitanja te kvalitete financijskog izvještavanja 
i revizije. U tom smislu, dane su brojne preporuke za daljnja istraživanja u ovom području koje se odnose na to u kolikoj mjeri doprinose dodatne informacije u izvješću neovisnog revizora investitorima i ostalim dionicima u sustavu korporativnog upravljanja. Kako bi proširili pregled dosadašnjih istraživanja, pregledana su izvješća neovisnih revizora na uzorku izdavatelja na Zagrebačkoj burzi.

U radu je analizirana struktura i sadržaj izvješća neovisnih revizora u godišnjim izvješćima društva izdavatelja na Zagrebačkoj burzi s posebnim naglaskom na objavljena ključna revizijska pitanja. Analizom strukture i sadržaja izvješća neovisnih revizora utvrđeno je kako se najčešća ključna revizijska pitanja odnose na priznavanje prihoda, što je u skladu s pretpostavkom da su prihodi najrizičnija stavka u financijskim izvještajima. Osim prihoda, značajne objave u izvješćima neovisnih revizora odnose se na priznavanje, vrednovanje i procjenu materijalne imovine, prije svega na nekretnine, postrojenja i opremu te najmove. Posebno se ističe značajan broj ključnih revizijskih pitanja koji je povezan s priznavanjem i vrednovanjem financijske imovine. Načelno, ostao je značajan broj objavljenih ključnih revizijskih pitanja koja se odnose na financijsku imovinu, iako su isključene iz uzorka financijske institucije koje imaju drugačiji sadržaj i strukturu financijskih izvještaja, što upućuje na to da ce značajan dio revizijskih postupaka i procedura biti usmjeren upravo $\mathrm{k}$ financijskoj imovini. $\mathrm{U}$ tom smislu može se zaključiti kako kompleksnost i složenost primjene Međunarodnih standarda financijskog izvještavanja koji se odnose na priznavanje, vrednovanje i procjene vezane uz financijsku imovinu i dalje ostaje izazov za revidirati kod izdavatelja iz realnog sektora. Isto tako, može se uočiti kako je objavljivanje ključnih revizijskih pitanja u velikoj mjeri povezano s djelatnošću u kojoj izdavatelj djeluje, što je u skladu s temeljnim revizijskim načelom obavljanja revizije na materijalno značajnim računima u financijskim izvještajima.

U tom smislu potrebno je istražiti može li se dokazati da objavljivanje ključnih revizijskih pitanja u izvješću neovisnog revizora ukazuje na veću kvalitetu revizije te daje li veći informacijski značaj korisnicima financijskih izvješća. Isto tako potrebno je usporediti objavljivanje ključnih revizijskih pitanja u više vremenskih razdoblja kako bi se dokazalo jesu li ona informativna korisnicima financijskim izvještaja. Naime, može se zaključiti kako su dokazi o tome da objavljivanje ključnih revizijskih pitanja značajno unaprjeđuje kvalitetu revizije financijskih izvještaja te utječe na tržišne reakcije investitora još uvijek neuvjerljivi te postoje različiti pristupi i dokazi u ovoj problematici. U tom smislu moguće je dati preporuke u vidu budućih istraživanja koja se odnose na dokazivanje povezanosti objavljivanja ključnih revizijskih pitanja i kvalitete revizije, a isto tako može se istražiti imaju li objave revizora u izvješćima značajan utjecaj na cijenu dionica izdavatelja. Naime, u uvjetima kada objave revizora doprinose tržišnoj reakciji moguće je očekivati značajne razlike u obujmu trgovanja tih izdavatelja.

\section{POPIS LITERATURE:}

1. Almulla, M. \& Bradbury, M. E., (2019). Auditor, Client, and Investor Consequences of the Enhanced Auditor's Report, Available at SSRN: https://ssrn.com/abstract=3165267 or http://dx.doi.org/10.2139/ssrn.3165267

2. Brozović, M. (2018). Odrednice kvalitete revizije u funkciji smanjenja jaza očekivanja korisnika revizije, doktorska disertacija, Ekonomski fakultet, Zagreb. 
3. Brozović, M., Mamić Sačer, I., Pavić, I., Sever Mališ, S., Tušek, B. \& Žager, L. (2020) REVIZIJA nadzorni mehanizam korporativnog upravljanja. Zagreb, Hrvatska zajednica računovođa i financijskih djelatnika.

4. Coram, P. J. \& Wang, L., (2019). The Effect of Disclosing Key Audit Matters and Accounting Standard Precision on the Audit Expectation Gap Available at SSRN: https:// ssrn.com/abstract=3485879 or http://dx.doi.org/10.2139/ssrn.3485879

5. Dahyda, R. (2019). Key audit matters in Enhanced Auditor's Report: Tracing Malaysia in its First Year Implementation, International Journal of Sciences and High Technologies, 13 (1), 39-45.

6. Direktiva 2006/43/EZ Europskog parlamenta i Vijeća od 17. svibnja 2006. o zakonskim revizijama godišnjih financijskih izvještaja i konsolidiranih financijskih izvještaja, kojom se mijenjaju direktive Vijeća 78/660/EEZ i 83/349/EEZ i stavlja izvan snage Direktiva Vijeća 84/253/EEZ Tekst značajan za EGP, dostupno na: https://eurlex.europa.eu/legal-content/HR/TXT/?uri=CELEX:32006L0043

7. Direktiva 2014/56/EU Europskog parlamenta i Vijeća od 16. travnja 2014. o izmjeni Direktive 2006/43/EZ o zakonskim revizijama godišnjih financijskih izvještaja i konsolidiranih financijskih izvještaja Tekst značajan za EGP, dostupno na: https://eur-lex. europa.eu/legal-content/HR/TXT/?uri=CELEX\%3A32014L0056

8. Ferreira, C. \& Morais, A. I. (2019). Analysis of the relationship between company characteristics and key audit matters disclosed, Revista Contabilidade\& Financas, 31 (83) http://dx.doi.org/10.1590/1808-057x201909040

9. Gold, A., Heilmann, M. (2019). The consequences of disclosing key audit matters (KAMs): A review of the academic literature, Maandblad voor accountany en Bedrijfseconomie 93 (1/2), 5-14 doi 10.5117/mab.93.29496

10. Gold, A., Heukmann, M., Pott, C., Rematzki, J. (2020). Do key audit matters impact financial reporting behavior? International Journal od Auditing, 24, (2). 232-244. https://onlinelibrary.wiley.com/doi/full/10.1111/ijau.12190

11. Gutierrez, E., Minutti-Meza, M., Tatum, K. W., Vulcheva, M., (2018). Consequences of adopting an expanded auditor's report in the United Kingdom, Review of Accounting Studies, 23, (4), 1543-1587.

12. IAASB (2011). Enhancing the Value of Auditor Reporting: Exploring Options for Change, Consultation paper

13. IAASB (2012). Improving the auditor's report available at: https://www.ifac.org/system/ files/publications/files/Auditor_Reporting_Invitation_to_Comment-final_0.pdf

14. IAASB (2015). International Standard on Auditing (ISA) 701 (new), communicating key audit matters in the independent auditor's report

15. International Standard on Auditing (ISA) 701, Communicating Key Audit Matters in the Independent Auditor's Report, - Međunarodni revizijski standard - Komuniciranje ključnih revizijskih pitanja u izvješću neovisnog revizora ISBN 978-1-60815-2049, prijevod s engleskog jezika, Hrvatska revizorska komora, 2016.

16. Kitiwong, W. \& Sarapaivanich, N. (2020). Consequences of the implementation of expanded audit reports with key audit matters (KAMs) on audit quality, Managerial Auditing Journal, 35 (8), 1095-1119. https://doi.org/10.1108/MAJ-09-2019-2410 
17. Lau, C. K. (2020). Measurement uncertainty and management bias in accounting estimates: the perspective of key audit matters reported by Chinese firms' auditors", Asian Review of Accounting, 29 (1), 79-95. https://doi.org/10.1108/ARA-07-2

18. Lennox, C. (2005). Audit quality and executive officers' affiliations with CPA firms Journal of Accounting and Economics 39, 201-231.

19. Lennox, C., Schmidt, J. J., Thompson, A. (2021). Why are expanded audit reports not informative to investors? Evidence from the UK Available at SSRN: https://ssrn.com/ abstract=2619785 or http://dx.doi.org/10.2139/ssrn.2619785

20. Levanti, D. A. (2019). Aspects Regarding the Changes to the Independent Auditor's Report. The Case of Public Interest Entities, The Audit Financiar journal, 17, (155), 486

21. Li, H. (2017). The Benefit of Assing Key Audit Matters to the Auditing Report, 2nd International Conference on Education, Management Science and Economics (ICEMSE 2017), Advances in Economics, Business and Management Research, Vol. 49.

22. Li, H., Hay, D. \& Lau, D. (2019). Assessing the impact of the new auditor's report, $P a$ cific Accounting Review, 31 (1), 110-132. https://doi.org/10.1108/PAR-02-2018-0011

23. Pratoomsuwan, T. \& Yolrabil, O. (2020). Key audit matter and auditor liability: evidence from auditor evaluators in Thailand, Journal of Applied Accounting Research, 21 (4), 741-762. https://doi.org/10.1108/JAAR-10-2019-0147

24. PWC (2014) Plain speaking! Benchmarking the new auditor's report among Dutch listed entities

25. Robu, M. A. \& Robu, I. B. (2015). The Influence of the Audit Report on the Relevance of Accounting Information Reported by Listed Romanian Companies, Procedia Economics and Finance, 20, 562-570, ISSN 2212-5671

26. Segal, M. (2019). Key audit matters: insight from audit experts, Meditari Accountancy Research, 27 (3), 472-494. https://doi.org/10.1108/MEDAR-06-2018-0355

27. Sever Mališ, S. \& Brozović, M. (2016) Komuniciranje ključnih pitanja revizije u izvješcu neovisnog revizora. Računovodstvo i financije, 62 (3), 49-53.

28. Suttipun, M. (2021). External auditor and KAMs reporting in alternative capital market of Thailand, Meditari Accountancy Research, Vol. ahead-of-print No. ahead-ofprint. https://doi.org/10.1108/MEDAR-04-2020-0850

29. Tušek, B., Ježovita, A. (2018) The Key Audit Matters as an Element of the Independent Auditor's Report - a Booster to the Corporate Governance // InterEULawEast : journal for the international and european law, economics and market integrations, V (2018), 2; 241-276 doi:10.22598/iele.2018.5.2.9

30. Uredba (EU) br. 537/20, 14 EUROPSKOG PARLAMENTA I VIJEĆA od 16. travnja 2014. o posebnim zahtjevima u vezi zakonske revizije subjekata od javnog interesa $\mathrm{i}$ stavljanju izvan snage Odluke Komisije 2005/909/EZ

31. Velte, P. (2019). Associations between the financial and industry expertise of audit committee members and key audit matters within related audit reports, Journal of Applied Accounting Research, 21(1),185-200. https://doi.org/10.1108/JAAR-10-20180163 
32. Velte, P., Issa, J. (2019). The impact of key audit matter (KAM) disclosure in audit reports on stakeholders' reactions: a Literature review. Problems and Perspectives in management, 17(3), 323-341., doi: 10.21511/ppm.17(3).2019.26

33. Wuttichindanon, S. \& Issarawornrawanich, P. (2020). Determining factors of key audit matter disclosure in Thailand, Pacific Accounting Review, 32(4), 563-584. https:// doi.org/10.1108/PAR-01-2020-0004

34. Zagrebačka burza (2021) Popis izdavatelja, dostupno na: https://zse.hr/hr/popis-izdavatelja/178

35. Zakon o računovodstvu, pročišćeni tekst zakona Narodne Novine br. 78/15, 134/15, $120 / 16,116 / 18,42 / 20,47 / 20$

36. Zakon o reviziji, Narodne novine br. 127. 2017, dostupno na: https://www.zakon. $\mathrm{hr} / \mathrm{z} / 417 / Z a k o n-o-r e v i z i j i$ 